\title{
QUO VADIS? FEW REMARKS ON IDENTITY OF ARCHIVES AND ARCHIVISTS WITHIN THE CONTEXT OF THE YEAR OF ARCHIVES
}

\author{
Gintaras Dručkus ${ }^{a}$, Kristina Stanišausk $\dot{e}^{b}$ \\ ${ }^{a, b}$ Kaunas Regional State Archives (Kaunas, Lithuania)
}

\section{INTRODUCTION}

The aims of the report:

- to introduce shortly Lithuanian state archives system and its dynamics over time; functions;

- to deal with the author's opinion concerning evolution of archives and archivist

- to share some personal insights concerning certain identity aspects of archives and archivists. Questions with (out) answers;

In spite of the fact that archives in Lithuania have been existing at least from the beginning of the 13th century, actual formation of the Lithuanian state archival system began only a hundred years ago - since 1921, when the order on the establishment of the Lithuanian Central Archives was signed.

It was under Soviet occupation - 60-ies of the 20th century - when formation of the Lithuanian state archival system was basically completed.

Since 1990, that is, after regaining Independence of the Republic of Lithuania State Archival system faced certain changes. Today it consists of nine independent legal entities subordinated to the Chief Archivist of Lithuania and they all together constitute Lithuanian State Archival System.

Through their history archives as institutions as well as archivists as individuals have experienced various trials and challenges. All this and other reasons and circumstances influenced changes in the mission and functions of archives and archivists.

All these challenges radically changed our traditional understanding about state archives and archivists - their mission, functions and professional requirements.

These and many other questions concerning archives and archivists identity confirm that the challenge exists. In spite of this, we do believe that all these challenges can be successfully turned into new opportunities. Nevertheless, for this at least one condition is necessary: not to lose our identity.

The report is prepared mainly on the basis of Kaunas Regional State Archives 'case as well as authors' personal twenty years professional experience. The authors are of the opinion that Kaunas Regional State Archives' case like every other state archives in Lithuania have certain own specialities in its development but still most of the statements in this report are basically suitable for describing the situation of the whole Lithuanian state archival system and its employees - archivists.

\section{LITHUANIAN STATE ARCHIVES SYSTEM AND ITS DYNAMICS OVER TIME}

The beginning of the formation of Lithuanian archives goes back to the beginning of the 13th century when Lithuanian State was formed. Nevertheless, until the very beginning of the 20th century archives in Lithuania should be defined first of all and mainly as departmental (office) archives: through ages we have had archives of our rulers' office (chancellery); archives of State Tribunal as well as various other court institutions; archives of State Treasury; archives of various cities magistrates and so on. Nevertheless, all this variety of archives hardly could be evaluated as state archives in modern sense of this definition. Nor can we speak of a state system of archives until at least the middle of the 20th century. 
So, in spite of the fact that archives in Lithuania have been existing at least from the beginning of the 13th century it is only the middle of the 20th century that one can notice formation of the state system of archives. Until the very end of the 18th century Lithuanian rulers, obviously, did not consider it necessary to create state archival system. Since the end of the 18th until the beginning of the 20th century Lithuania was under Russian Empire occupation and had no possibilities to form its own state archives' system. The Central Archives of Ancient Acts (Records) established in 1852 (the circumstances of the establishment of the Central Archive of Ancient Acts in Vilnius in 1852 and its activities are the topic of a special study and a separate article, and therefore are not discussed in this report) as well as a number of departmental archives of various institutions which were operating at that time within the boundaries of nowadays Lithuania territory were integral part of Russian Empire archival system. For these reasons actual formation of the Lithuanian state archival system began only a hundred years ago - since 1921, when then Minister of Education Kazys Bizauskas signed a decree on the establishment of the Lithuanian Central Archives [1]. So, we should emphasize once again, that on one hand, Lithuanian archives count almost a thousand years of their history. Though on the other hand, it is only the last centenary that we can talk about Lithuanian State Archives and Lithuanian State archival system as such.

To be honest, even in the first half of the 20th century, Lithuania being already free and independent, Lithuanian authorities did not consider archival field as especially meaningful priority of the State. To illustrate such a point of view it should be enough to mention that in 1921 it was refused to establish Central State Archives neither by the law adopted by the supreme power of the Republic of Lithuania - Seimas (Parliament) nor by the decision of the Government. The Cabinet of Ministers, at the meeting on October 7, 1921, discussed the draft of the law on the establishment of the Central State Archives and decided that it will be sufficient if the Central State Archives was managed by decrees of the Minister of Education [2]. So, the establishment of Lithuanian State Archives in 1921 was delegated to the Minister of Education and was realized by his decree from October 19, 1921 [1]. One more illustration of this statement - during the entire period of independent Republic of Lithuania (that is, 1921-1940) we had neither Law on Archives nor the Law on Documents. First Law on Archives in Lithuania was adopted just in few months after Lithuanian occupation by the Soviet Russia - on August 23, 1940. It was signed by Prime Minister who was then executing duties of the President of the Soviet Republic of Lithuania [3].

Since 1921 until 1939 there was only one state archive in Lithuania. As Lithuanian capital was occupied by Poland, it was operating in Kaunas - provisional capital of Lithuania. At the very end of 1939 - beginning of 1940 the number of Lithuanian state archives increased up to two: Central Archives moved to Vilnius while archives in Kaunas continued its activities as a branch of the Central Archives in Vilnius.

It was under the Soviet occupation - in the 60-ies of the 20th century - when formation of the Lithuanian state archival system was basically completed. Those times Lithuanian state archival system was strictly centralized with clearly expressed hierarchy. On the eve of regaining of Lithuanian Independence there were Lithuanian State History Archives, preserving documents since the earliest times up to 1918; Lithuanian Central State Archives, preserving documents since 1918 until current time; Cinema-photo-phono archives, preserving video and audio archival materials; Archives of Literature and Art; and a number of regional archives operating as branches of the Central State Archives and, according to the Soviet regulation of archival field, preserving mainly local importance archival documents of the certain territory mostly since 1944. Exception - those times Kaunas branch. Chronological frames of the preserved documents in Kaunas - since the beginning of the 19th century (individual documents go back to the 17th century) until nowadays. All these archives were subordinated to the Board of Archives under the Council of Ministers. 
Since 1990, that is, after regaining Independence of the Republic of Lithuania State Archival system faced certain changes. Today it is partially decentralized and consists of nine independent legal entities:

- Lithuanian State History Archives (established in 1852/1963);

- Lithuanian Central State Archives (est. 1921/1941);

- Lithuanian State Modern Archives (est. 1993);

- Lithuanian Archives of Literature and Art (est. 1968);

- Lithuanian Special Archives (est. 1995);

- Kaunas Regional State Archives (est. 1921/1941. Branches in Alytus and Marijampole);

- Klaipėda Regional State Archives (est. 1945. Branches in Taurage and Telshiai);

- Shiauliai Regional State Archives (est. 1944. Branch in Panevezhys);

- Vilnius Regional State Archives (est. 1996. Branch in Utena).

These nine state archives are subordinated to the Chief Archivist of Lithuania and they all together constitute Lithuanian State Archival System.

\section{LITHUANIAN STATE ARCHIVES SYSTEM AND ITS DYNAMICS OVER TIME}

Through their history archives as institutions as well as archivists as individuals have experienced various trials and challenges. All this and other reasons and circumstances influenced changes in the mission and functions of archives and archivists. Perhaps the main requirement for archives since the very beginning up to approximately 19th century was perhaps to preserve necessary archival documents first of all for legal purposes - to have written evidences for various social and political needs. In addition to this perhaps since the 19th century archives are already widely used as the source of information for various investigations. What concerns Lithuania, according to the Minister of Education Decree on establishment of the Central State Archives it was to preserve documents of governmental as well as municipal institutions archives, to accumulate unnecessary for daily needs documents and those of liquidated institutions as well as documents of private persons, nongovernmental organizations that are of state, public and scientific value. Nevertheless, in spite of this, in 20-30-ies of the 20th century Lithuanian Central Archives was mainly just preserving archival documents. It did not fulfil neither acquisition of documents, nor appraisal. Reading room of the Archives was opened in 1934 only [4]. To be honest - during the Interwar period (20-30-ies of the 20th century) attention of the highest authorities of that time towards archives and archival work was, to put it mildly, insufficient.

For a long time, however, archives were little-known, closed institutions. Just after regaining Lithuanian Independence (by the end of the 20th century) new roles of state archives were included to the agenda of state archives' activities. Evolution of archival functions took place especially intensively in Lithuania since the very beginning of the 21 st century and this process is still going on. Let's take, for example, a direction that was put forward for the openness of archives. One of the challenges realizing this task is that nowadays archives and archivists face strongly expressed expectations of society to be the more the better more open, more visible, more accessible and so on. To tell the truth our nowadays society is, actually, consumption and „Google society“ which expect that state archives should be like supermarket where one could get anything he or she needs - without any restrictions, in full. And - at once, of course. When such persons come to archives they feel themselves deeply disappointed, because they are not eager to spend long hours in the archives' reading room looking for information they need.

Few years ago, co-author of this report Mrs. Kristina Stanishauske has conducted a study on the compliance of documents stored in the archives with the needs of the public and presented the results of the study, besides others, at the Conference held in Kiev in November 2017. We just shortly remind that he main results of that analysis were that within the 2003-2014 period Kaunas 
Regional State Archives has received 61301 requests (inquiry) for archival certificates for approval of legal (juridical) facts. The main part of them consisted of requests related to person's work experience $(40,35 \%)$; notary acts $(21,56 \%)$ and inquiries related to real estate $(11,26 \%)$. I would like to draw your attention to the fact that nowadays all these types of documents are not classified as permanent storage documents. Moreover, 8968 inquires $(15 \%)$ were not answered for the reason that such kind of archival documents are not preserved at the State Archives of Lithuania at all [5]. Few years later, at the Meeting of the Baltic Countries Archivists' ${ }^{6}$ Mrs. Kristina Stanishauske introduced more detailed version of the same problem [6].

Kaunas Regional State Archives together with its Alytus and Marijampole branches supervises the document management of State and Municipal Institutions, Bodies and Enterprises operating in Kaunas County - 66, Alytus County - 31 and Marijampole County - 32. In total - that is, in all these three counties - one hundred and twenty-nine legal entities which, according to our legislation should transmit their activities' documents to the Kaunas Regional State Archives for permanent preservation [7]. Over time, this list is steadily shrinking, the number of institutions transmitting documents to the state archives for permanent storage and, in particular, the volume of documents transmitted is steadily declining. Few questions in brief: is the list of the governmental bodies, institutions and enterprises complete and sufficient? Are we, archivists, sure that we are collecting and preserving particularly those documents that we should to? By the way, recently we are facing a growing demand of evidences confirming one's right to citizenship. And, once again - state archives do not collect documents related to citizenship.

Special mention should be made of the active invasion of modern information technologies into the state archives sector, as this shook the archives system and was one of the basic reasons for a number of significant changes. In addition to intensive large-scale application of information technologies in the state archives sector one more meaningful change took place electronic documents era started. In connection with this a predominant but very worrying trend has emerged towards reducing the volume of documents. First of all, this is being realized by shortening of the retention periods for documents under the guise of reducing administrative burden and under the same pretext - reducing the circulation and volume of paper documents in general. One more example:

1. Since the January 1, 2020, the obligation to the state and municipal institutions, bodies and enterprises transmitting their documents to the state archives to include long retention term documents into documents' account records (inventories) was eliminated. Also, there is no more obligation to provide long term documents accounting documents (inventories) or their data for approval (reconciliation) to the certain supervising them state archives [8].

2. Following the order of the Chief Archivist of Lithuania on approval of the description of the preservation of paper documents in electronic form which came into power since July 1 , 2020, legal preconditions were created for the destruction of originals of short and long-term storage paper documents and their further preservation in electronic form [9].

In brief, the ongoing documents management reform aims to create appropriate legal preconditions for the following:

- to reduce number of official documents within particular institutions documents' management systems. This should be realized by transferring official documents from appropriate activities' fields documents' management systems to the central appropriate activities' fields information systems (e-tar; info-statyba, etc.);

- to reduce documents' retention periods;

- to move gradually from official documents management to data entries management;

- simplify documents' management processes and procedures;

- to establish requirements for the selection and storage of paper documents in electronic form, thus not preserving the original of the created document;

- refuse description of requisites' layout and determine which elements of the document are mandatory; 
- refuse the signature as a required requisite;

- enable institutions to transfer/transmit digital copies of documents to the state archives;

- refuse mandatory numbering of pages of short and long term preservation documents completed files as well as preparation of accounting documents (inventories), etc.

One more problem, perhaps especially new and unusual for state archives is the everincreasing and growing pressure on archives to engage themselves into activities related to the dissemination of archival documents and various educational and public relations activities.

As we see, ongoing documents management reform aims to create not only appropriate legal preconditions for reducement of documents volume, but to change our understanding towards state archives and documents' management (paper document versus electronic one; document versus data entry; original version versus electronic/digital version, mission of state archives and archivists, etc.). All these mentioned above and some other challenges are radically changing our traditional understanding about state archives and archivists - their mission, functions and professional requirements.

So to say "traditional" archives' mission was to accumulate and preserve written evidences ensuring historical memory of the nation and the state in appropriate content and quantity.

So to say „traditional“ archivist was to be hardworking, diligent, responsible, with a knowledge of history and able to understand and speak at least several languages. While the requirements for nowadays archivists are, first of all, to be able to communicate, disseminate and promote the idea of archives among the public, to prepare various educational activities, to be skilled in using information technologies. To be able to write and publish articles but preference is given to promotional articles that are easy to read and understand rather than the research ones. We do agree that all this is helpful for nowadays archivist. That digital Era opens up new possibilities. We are happy and proud that we have possibility to spread the word about the archives and its activities through the archives' website, account on the Facebook social network; that we can invite people to our educational events, exhibition presentations not only directly but also remotely; that anyone interested in our preserved documents can access our document descriptions through the electronic archive information system; that after successful implementation of the project Kaunas Regional State Archives has created a virtual educational space of the Kaunas Regional State Archive www.slaptazodis-archyvas.lt, etc.

\subsection{Identity of archives and archivists. Questions with (out) answers}

In the face of public expectations, rapid development of modern information technologies we should stop, take a breath, delve into the situation and, above all, answer ourselves some questions - Such as:

- do we really select archival documents for permanent preservation exactly those, exactly in the right way and exactly what is most needed today and for future generations?

- how much attention and resources we should devote to the creation and development of databases, information retrieval tools, remote access to archival documents?

- what should be reasonable relation in between archives and modern technologies, etc.?

Nevertheless, in spite of modern society requirements, in spite of all Digital Era advantages we, archivists, should deeply and clearly comprehend responsibility for preserving our memory, our history, our identity. Once we agree that namely this is perhaps the main priority of archives on the whole then it will be easier for us to maintain a healthy and reasonable attitude towards Digital Era provided opportunities which are, undoubtedly, wide range, impressive and in many cases helpful. On the other hand, we are facing a challenge in which direction state archives should developed as a subject as well as human resources of our archivists' community: either towards deeper professional understanding of the archival documents as such and documents' management or towards effective handling of information technologies and public relations techniques? 
These and many other questions concerning archives and archivist's identity confirm that the challenge exists. And that it is really a serious challenge. Nevertheless, fact that we still do not have proper answers to these questions should not be upsetting. Let all this encourage us for defining proper place of state archives and archivists in this dynamic world in order to define correctly the place and purpose of the state archives field. We wish that in the face of various challenges in a rapidly changing world, archivists successfully turn all these challenges into new opportunities. And, of course - we should take care of archives' and archivists' identity in order not to lose it. If we are concerned for our nation and state historical identity we must first and foremost adequately understand and preserve our own one.

\section{CONCLUSIONS}

- Origin of archives in Lithuania goes back to the beginning of the 13th century and is related with the emergency of Lithuanian State. Nevertheless, it was the first half of the 20th century only when real formation of Lithuanian state archives system started.

- At the end of the 20th century there was a turning point in the development of the Lithuanian state archives system, which was determined by the needs of society and the invasion of high technologies into the state archives sector.

- Ongoing documents management reform aims to create not only appropriate legal preconditions for reducement of documents volume, but to change our understanding towards archives and archival documents (paper document versus electronic one; document versus data entry; original version versus electronic/digital version, etc.).

- Modern society requirements as well as Digital Era advantages open up lots of new possibilities for archives and archivists as well as puts forward and actualizes questions concerning the further development of archives, their mission and functions.

- All these challenges can be successfully turned into new opportunities. Nevertheless, for this at least one condition is necessary: not to lose our identity.

\section{ACKNOWLEDGEMENTS}

Special thanks to the all those who have made this conference to happen, because only while discussing and sharing our opinions and experiences we can achieve our main archival purpose - to preserve for the future. Exceptional thanks for Iryna Tiurmenko, Head of the History and Records Management Department of the Humanities Institute of NAU, for her energy and encouragement to work archival studies knowledge. Also, for Lithuanian state archives colleagues for the support and advises.

\section{REFERENCES}

[1] Minister of Education Decree on establishment of the Central State Archives, fond 391, inventory 4, file 1017, list 171-171 opposite side, Lithuanian Central State Archives, Lithuania, Vilnius, 1921.

[2] Minister of Education Decree, fond 923, inventory, 1, file 169 (A-50), list 201, Lithuanian Central State Archives, Lithuania, Vilnius, 1921.

[3] Law on Archives, Government Statements No. 727, Lithuania, Kaunas, 1940.

[4] Lithuanian Central State Archives. History, 2021. URL: https://www.archyvai.lt/lt/apie 168/ istorija_169.html.

[5] K. Stanishauske, Memory of Nation. Archivist's Responsibility, Report, the 2nd International Scientific and Practical Conference "Historical and Cultural Heritage: Preservation, Access, Use", National university of Ukraine, Kiiv, 2017.

[6] Stanishauske Kristina, Archival Documents' Appraisal and Collection in Time Perspective: The Kaunas Regional State Archives' Case, Report, Baltic States Archivists’ Meeting, Estonia, Pärnu, 2019.

[7] Order of the Chief Archivist of Lithuania from December 15, 2020 No.VE-100 "On Amendment of the Order of the Chief Archivist of Lithuania from December 20, 2011. V-153 "On the Approval of the List of State and Municipal Institutions, Bodies and Enterprises Transmitting Their Documents to the State Archives”, 2021. URL: https://www.e-tar.lt/portal/lt/legalAct/68ad90a03eb511eb8d9fe110e148c770.

[8] Rules on documents management and accounting. Approved on July 4, 2011 by the Order of the Chief Archivist of Lithuania No. V-118 (subsequent version of the document - Order of the Chief Archivist of 
Lithuania No. VE-68 from December 12, 2019), paragraph No. 4.4, 2021. URL: https://www.etar.lt/portal/lt/legalAct/TAR.C21AD42B2592/asr.

[9] Order of the Chief Archivist of Lithuania No. VE-73 from December 19, 2019 on approval of the description of the preservation of paper documents in electronic form, 2021. URL: https://eseimas.lrs.lt/portal/legalAct/lt/TAP/81cc2bc0be8511e993cff47c25bfa28c ? positionInSearchResults=0 